\title{
Occurrence of concavities on the lorica of two species of Testudinella (Rotifera, Monogononta, Testudinellidae)
}

\author{
Paula Nunes Coelho ${ }^{1 *}{ }^{-}$, Louizi Souza Magalhães Braghin ${ }^{2}$, Fabio Amodêo Lansac-Tôha ${ }^{\mathbb{D}} \&$ \\ Raoul Henry ${ }^{1}$ \\ ${ }^{1}$ Universidade Estadual Paulista, Instituto de Biociências, Departamento de Zoologia, 18618-970, \\ Botucatu, SP, Brasil \\ ${ }^{2}$ Universidade Estadual de Maringá, Núcleo de Pesquisas em Limnologia, Ictiologia e Aquicultura, \\ Maringá, PR, Brasil \\ *Corresponding author: Paula Nunes Coelho, e-mail: paulinhancoelho@gmail.com
}

COELHO, P.N., BRAGHIN, L.S.M., LANSAC-TÔHA, F.A., HENRY, R. Occurrence of concavities on the lorica of two species of Testudinella (Rotifera, Monogononta, Testudinellidae). Biota Neotropica. 19(2): e20180633. http://dx.doi.org/10.1590/1676-0611-BN-2018-0633

\begin{abstract}
Testudinella is a taxon of Rotifera broadly distributed in Brazil. In a recent collection in marginal lakes connected to the Paranapanema River (São Paulo, Brazil), we found specimens of Testudinella mucronata and T. patina with concavities on their lorica. The objective of this study was to describe the concavities observed in individuals of both species and discuss their possible causes. Plankton samples were collected at two sampling stations, in the pelagic (PZ) and littoral (LZ) zones of the Panema and Coqueiral lakes; both of these lakes are ultra-oligotrophic and not polluted. For T. mucronata, 4\% of individuals with concavities were found in the PZ of Coqueiral lake and 50\% in the LZ of Panema lake. In T. patina, the proportion of specimens with concavities corresponded to $34 \%$ in the $\mathrm{LZ}$ of Panema lake and 17\% in PZ of Coqueiral lake. In this study, we discussed that low water temperatures, predation events and/or recent hatching are factors that may justify the concavities in the lorica of specimens of our work.
\end{abstract}

Keywords: Freshwater environments, marginal lakes, morphology, rotifers, polymorphism.

\section{Ocorrência de concavidades na lórica de duas espécies de Testudinella (Rotifera, Monogononta, Testudinellidae)}

Resumo: Testudinella é um táxon de Rotifera amplamente distribuído no Brasil. Em recentes coletas em lagos marginais conectados ao rio Paranapanema (São Paulo, Brasil), nós encontramos espécimes de Testudinella mucronata e $T$. patina com concavidades em suas lóricas. O objetivo do estudo foi descrever as concavidades observadas em indivíduos de ambas as espécies e discutir suas possíveis causas. Amostras de plâncton foram coletadas em duas estações de amostragem, na zona pelágica (PZ) e litorânea (LZ) dos lagos Panema e Coqueiral; ambos os lagos são ultra-oligotróficos e não poluídos. Para T. mucronata, 4\% dos indivíduos com concavidades foram encontrados na PZ do lago Coqueiral e 50\% na LZ do lago Panema. Em T. patina, a proporção de espécimes com concavidades correspondeu a 34\% na LZ do lago Panema e 17\% na PZ do lago Coqueiral. Nesse estudo, nós sugerimos que baixas temperaturas da água, eventos de predação e/ou recente eclosão são fatores que podem justificar as concavidades na lórica dos espécimes do nosso trabalho.

Palavras-chave: Ambientes de água doce, lagos marginais, morfologia, rotíferos, polimorfismo. 


\section{Introduction}

Rotifera are small animals with two peculiar structures called ciliated corona and mastax (Wallace et al. 2006). The representatives of this Phylum are distributed globally in both marine and freshwater ecosystems (e.g., Eriksen 1968; Sarma \& Elias-Gutierrez 1997; Sharma $\&$ Sharma 2005; Fontaneto et al. 2008). Segers (2008) reported 2,031 described species for Rotifera; currently this number is probably greater due to numerous recent descriptions (e.g., Segers \& Walsh 2017).

Many monogonont rotifers are well known to respond to environmental factors with morphological variations in their body. This phenomenon is known as polymorphism and is usually caused by kairomones from predators, variations in water temperature and food availability (see review of Gilbert 2017; 2018). In general, polymorphism in rotifers has great relevance because morphological variations can influence life history, population dynamics and ecological interactions (Gilbert, 2017). Moreover, laboratory bioassays demonstrated that environmental pollution of metals can change the size and morphology of rotifers (Ríos-Arana et al. 2007, Xue et al. 2017).

Testudinella Bory de St. Vincent, 1822 (Monogononta, Testudinellidae) is a rotifer taxon composed of approximately 40 valid species (Segers 2007), of which 18 occur in Brazilian waters (Garraffoni \& Lourenço 2012). Among these species, Testudinella patina (Hermann, 1783) and T. mucronata (Gosse, 1886) are found in lakes (e.g., Garcia et al 1998; Casanova et al. 2009; Maia-Barbosa et al. 2014) and many freshwater ecosystems throughout the country (see Garraffoni \& Lourenço 2012).

During a study conducted in two marginal lakes to the Paranapanema River (São Paulo State, Brazil), we collected specimens of T. patina and T. mucronata with the presence of concavities on the lorica. In this work, we describe the cases and discuss possible causes of the presence of these concavities.

\section{Material and Methods}

\section{Study area}

Panema (2331'29"S; 48³8'55.4”W) and Coqueiral lakes (2329'24'S; 48³7'10.9' W) are marginal environments connected to the Paranapanema River at its mouth zone, flowing into the Jurumirim Reservoir (São Paulo State, Brazil) (Figure 1). The average depth is $1.2 \mathrm{~m}$ for Panema lake and $2.5 \mathrm{~m}$ for Coqueiral lake; these lakes have total areas of 0.07 and $0.582 \mathrm{~km}^{2}$ (Silva \& Henry 2013), respectively. Coqueiral lake is dominated by extensive coverage of macrophytes, while Panema lake has low abundance of aquatic vegetation.

\section{Data collection and analysis}

Samples were collected in April 2017 (rainy season), from two sampling stations, in the pelagic (PZ) and littoral zones (LZ) of each of the studied lakes. The water surface temperature was measured with a Toho Dentam thermometer, $\mathrm{pH}$ with a Micronal B-380 pH meter and the electrical conductivity with a Hach Mod. 2511 conductivimeter. The dissolved oxygen concentration of the water was determined by the method of Winkler, modified by Golterman et al. (1978). The total phosphorus and nitrogen concentrations were determined according to Strickland \& Parsons (1960) and Mackereth et al. (1978), respectively.
The chlorophyll- $a$ concentration was determined using the $90 \%$ acetone extraction method (Golterman et al. 1978). The trophic state index was calculated to classify the trophic level in both zones of the lakes (Cunha et al. 2013).

Rotifers were collected with a plankton net (50 $\mu \mathrm{m}$ mesh size), by means of a vertical trawl in the water column. The filtered volume (V) was calculated by the formula $\mathrm{V}=\pi \cdot \mathrm{r}^{2}$.d, where $\mathrm{r}$ is radius of plankton net opening and $d$ is the distance traveled by the net. Water sampling was conducted in order to result a filtered final volume of $100 \mathrm{~L}$. Subsequently, the organisms were fixed with a $4 \%$ formaldehyde solution saturated with sugar. The counting of sampled individuals was carried out in a minimum of four subsamples of 1 $\mathrm{mL}$, in a Sedgewick-Rafter chamber under an optical microscope; abundance was expressed in terms of individuals. $\mathrm{m}^{-3}$. The organisms were identified based on specialized literature (Koste 1978, Sharma 1990, Shiel 1995).

In order to estimate the frequency of individuals with concavities, two categories were established based on the external morphology for Testudinella mucronata (individuals were sorted based on the presence and absence of concavities; see Figure 2). Three categories were designated for T. patina (absence of concavities; Type 1 - presence of a concavity on the lorica; Type 2 - more than two concavities on the lorica; Figure 3). This nomenclature (i.e., Type 1 and Type 2) was used for Cladocera (see Melo et al. 2017) and adapted herein to apply to Rotifera as well.

A student's t-test was used to verify significant differences between limnological variables and zones of each lake. Normality assumptions were performed with the Shapiro-Wilk test. We used the level of statistical significance of $95 \%(\mathrm{p}<0.05)$. Statistical analyses were performed in R software (R Development Core Team, 2016).

\section{Results}

In general, high mean values of water temperature and electric conductivity were recorded in Panema lake, while low dissolved oxygen concentrations were found in Coqueiral lake (Table 1). In both lakes, the $\mathrm{pH}$ was neutral. Total phosphorus and nitrogen concentrations were low in both lakes. In relation to the limnological variables between the compartments of the lakes (pelagic and littoral zone), there was no significant difference between both lakes ( $p>0.05)$. The trophic status indexes showed that the lakes are composed of ultra-oligotrophic waters, in both the pelagic and littoral areas (Table 1).

Concavities were observed in individuals of both species of rotifers. In the case of Testudinella mucronata, several concavities were observed on the lorica of the individuals (Figure 2). In both lakes, the densities of affected organisms reached 59 ind. $\mathrm{m}^{-3}$ in littoral zone of the Panema lake and 33 ind. $\mathrm{m}^{-3}$ (pelagic zone) in Coqueiral lake (Figure 4). For this species, $4 \%$ of individuals with concavities were found in the $\mathrm{PZ}$ of Coqueiral lake and $50 \%$ in the LZ of Panema lake. In T. patina, the concavities were classified as Type 1 and Type 2 (Figure 3 ). The total density of specimens with Type 1 and Type 2 concavities for this taxon were 24 ind. $\mathrm{m}^{-3}$ in Coqueiral lake and 118 ind. $\mathrm{m}^{-3}$ in Panema lake (Figure 5). The total proportion of organisms with both types of concavities observed in T. patina corresponded to $34 \%$ in LZ of Panema lake and $17 \%$ in the $\mathrm{PZ}$ of Coqueiral lake. 
Ocorrence of concavities in Testudinella spp.

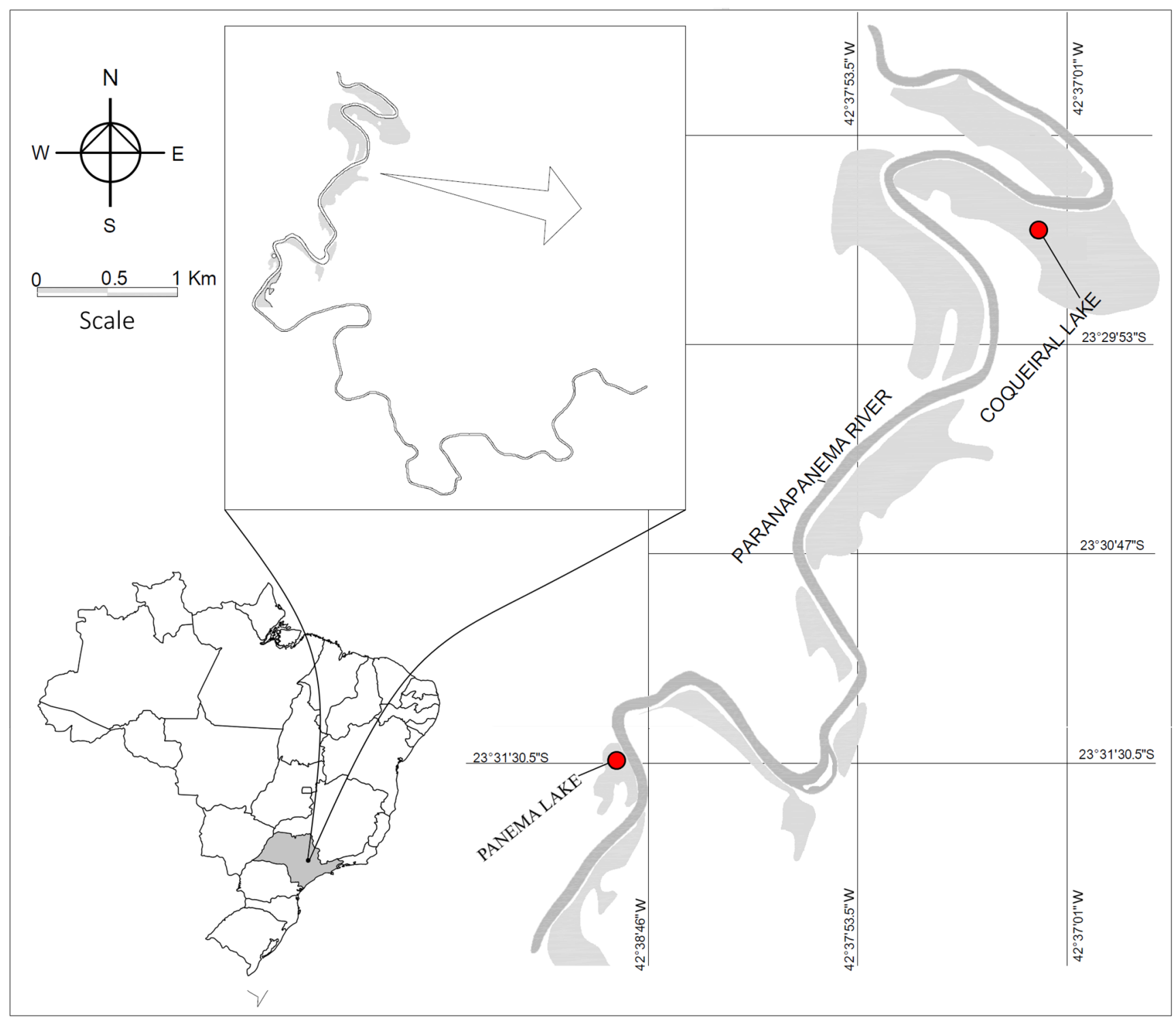

Figure 1. Localization of the sampling stations (red circle) in two marginal lakes on the Paranapanema River, São Paulo, Brazil.

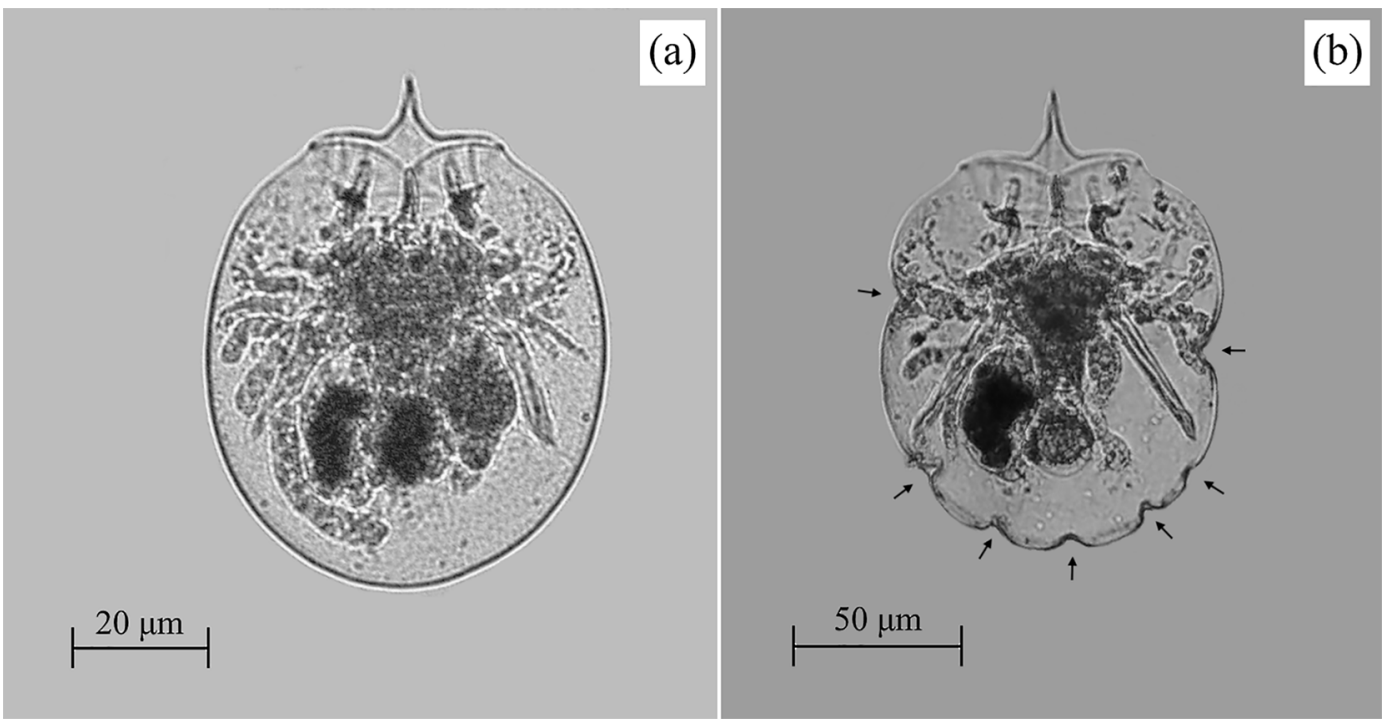

Figure 2. Testudinella mucronata with absence (a) and presence of concavities (b). The arrows indicate the locations of the concavities. 


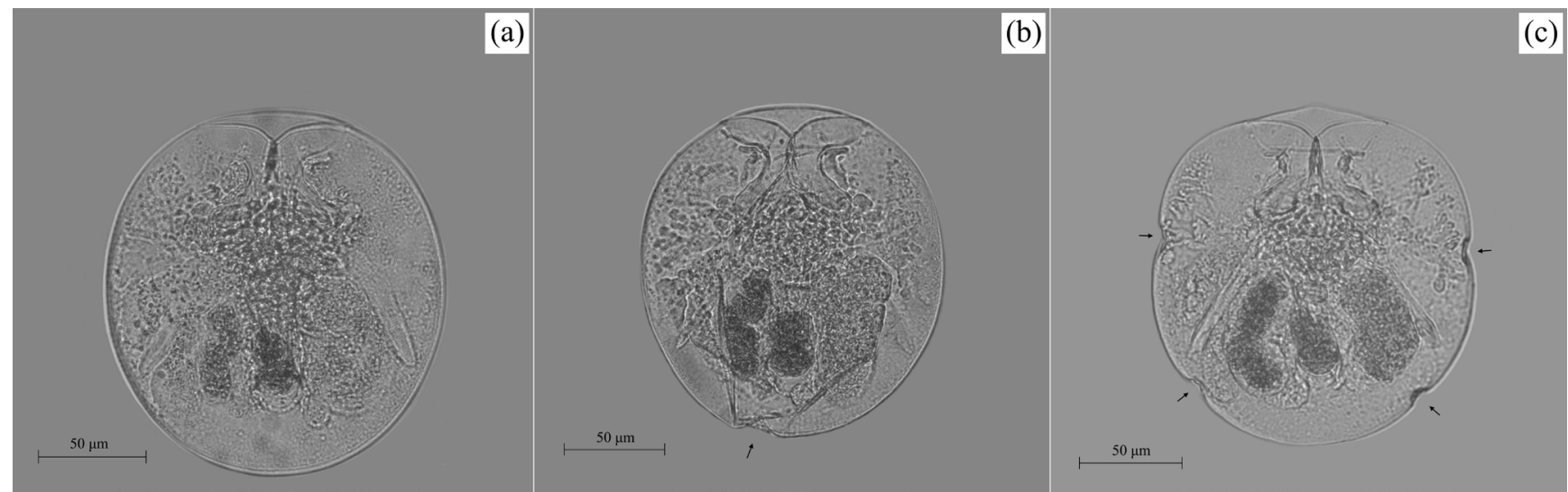

Figure 3. Testudinella patina with absence (a) presence of Type 1 (b) and Type 2 concavities (c). The arrows indicate the locations of the concavities.

Table 1. Mean and standard deviation of the physical and chemical variables of water in the pelagic and littoral zones of Coqueiral and Panema lakes (April 2017).

\begin{tabular}{lcccc}
\hline \multirow{2}{*}{ Variables } & \multicolumn{2}{c}{ Pelagic } & \multicolumn{2}{c}{ Littoral } \\
\cline { 2 - 5 } & Coqueiral & Panema & Coqueiral & Panema \\
\hline Temperature $\left({ }^{\circ} \mathrm{C}\right)$ & $25.58 \pm 0.25$ & $26.6 \pm 0.12$ & $25.7 \pm 0.05$ & $6.2 \pm 0.18$ \\
$\mathrm{pH}$ & $7.0 \pm 0.04$ & $6.8 \pm 0.04$ & $6.8 \pm 0.05$ & 5.05 \\
Electric conductivity $\left(\mu \mathrm{S} . \mathrm{cm}^{-1}\right)$ & $56.9 \pm 1.4$ & $92.5 \pm 0.86$ & $56.9 \pm 0.69$ & $2.4 \pm 0.29$ \\
Dissolved oxygen $\left(\mathrm{mg} . \mathrm{L}^{-1}\right)$ & $2.9 \pm 0.05$ & $5.1 \pm 0.05$ & $6.6 \pm 3.43$ & $5.9 \pm 0.10$ \\
Total phosphorus $\left(\mu \mathrm{g} . \mathrm{L}^{-1}\right)$ & $6.8 \pm 3.08$ & $7.4 \pm 5.68$ & $320.2 \pm 64.48$ & $401.9 \pm 17.65$ \\
Total nitrogen $\left(\mu \mathrm{g} . \mathrm{L}^{-1}\right)$ & $309.3 \pm 47.81$ & $355.6 \pm 65.19$ & $45.1 \pm 0.96$ & $47.4 \pm 0.62$ \\
Trophic status index & $47.3 \pm 0.45$ & $45.9 \pm 0.86$ & $0.19 \pm 0.01$ & $0.10 \pm 0.03$ \\
Chlorophyll- $a\left(\mu \mathrm{g} . \mathrm{L}^{-1}\right)$ & $0.69 \pm 0.17$ & $0.21 \pm 0.08$ & & \\
\hline
\end{tabular}

口Absence $\square$ Presence

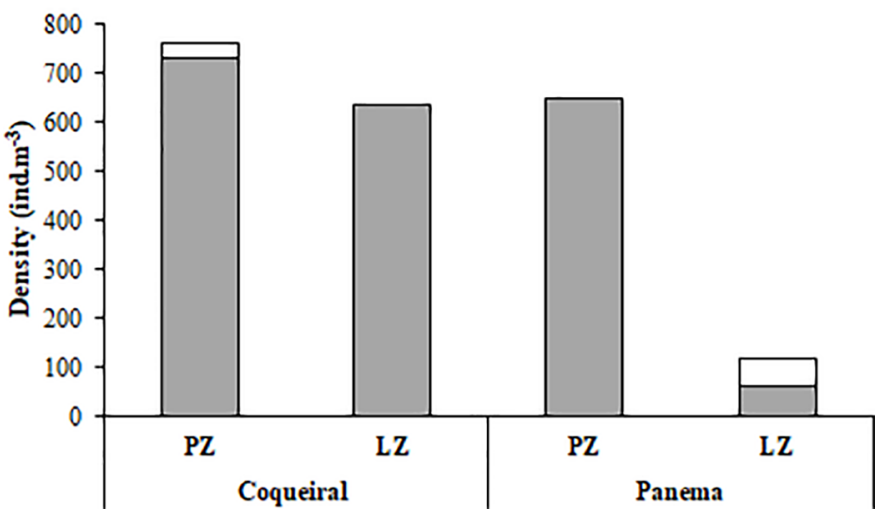

Figure 4. Density of individuals (ind. $\mathrm{m}^{-3}$ ) with absence and presence of concavities in Testudinella mucronata collected in two marginal lakes (São Paulo State, Brazil). PZ = pelagic zone and LZ = littoral zone.

\section{Discussion}

Morphological alterations in zooplankton may be caused by human impacts on aquatic environments (e.g., Montú and Gloeden 1982, Dias et al. 1999, Souza et al. 2011, Melo et al. 2017). In Rotifera, for instance, Zurek (2006) recorded deformations on the spines of Keratella cochlearis (Gosse, 1851) caused by the exposure to sulfides or derivatives present in the water from a sulfur mine impoundment. Ecotoxicological tests have also shown that heavy metals and pesticides

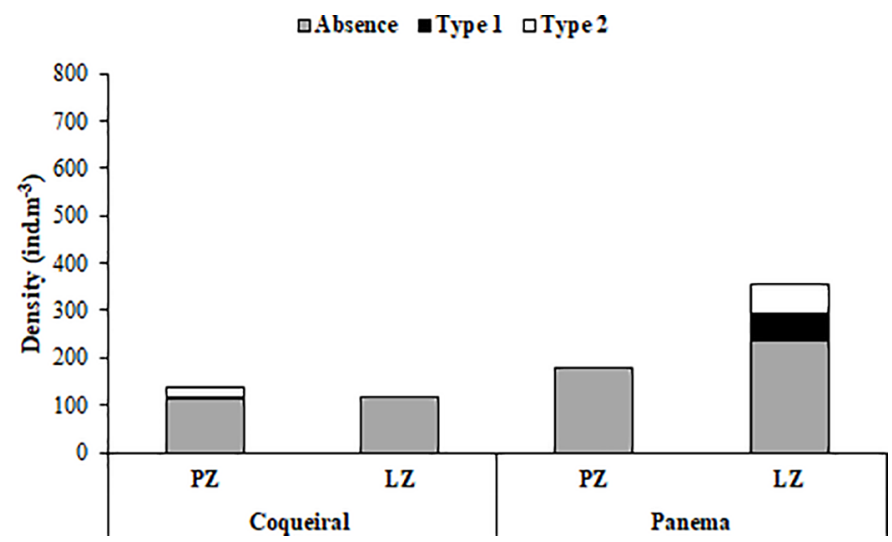

Figure 5. Density of individuals (ind. $\mathrm{m}^{-3}$ ) with absence and presence of concavities of Type 1 and Type 2 in Testudinella patina collected in two marginal lakes (São Paulo State, Brazil). PZ = pelagic zone and LZ = littoral zone.

induce morphological changes in the rotifer Plationus patulus (Müller, 1786) (Ríos-Arana et al. 2007) and Brachionus calyciflorus Pallas 1766 (Alvarado-Flores et al. 2015). In our study, concentrations of phosphorus and total nitrogen in lakes were around $7 \mu \mathrm{g} . \mathrm{L}^{-1}$ and $355 \mu \mathrm{g} . \mathrm{L}^{-1}$, respectively. When comparing these values with the reference conditions for nitrogen (300-350 $\left.\mu \mathrm{g} . \mathrm{L}^{-1}\right)$ and total phosphorus (10-15 $\left.\mu \mathrm{g} . \mathrm{L}^{-1}\right)$ established in subtropical reservoirs with different levels of enrichment (Cunha et al. 2012; Cunha \& Calijuri 2011), we concluded that the lakes studied here are relatively nutrient depleted. In addition, the trophic 
status index showed that the lakes were classified in ultra-oligotrophic category, suggesting that the trophic state of the environments is not related to the presence of concavities in Testudinella. While we did not performed metal analyses, we believe that metals are not the cause of the concavities. Both lakes, despite their riverine connections, are not near any pollution sources and their environments are ultra-oligotrophic.

On the other hand, there are reports of polymorphism in some Rotifera species of the Brachionidae family (Stemberger \& Gilbert 1984, see Gilbert 1999). This phenomenon can be induced by several environmental factors, including temperature variations (e.g., Gilbert 2018, Ge et al 2018). For example, some studies report that the temperature is responsible for lengthening spines of lorica in B. falcatus (Zacharias, 1898) and K. cochlearis (Bielañska-Grajner 1995; Ahad $\&$ Rao 2017). At low temperatures, the population growth rate of $K$. cochlearis decreases, resulting in the occurrence of organisms with longer caudal spines (Lindström \& Pejler 1975). In the present study, there was no significant difference in limnological variables between the pelagic and littoral zones of the lakes. However, our study didn't include the temporal scale. The occurrence of concavities may also be due to the colder riverine influx, since both lakes are connected to the river channel. Studies carried out in lacustrine environments in the same region related the influence of the lateral influx of water from the river on the limnological variables and planktonic community (Casanova et al. 2009; Henry et al. 2011).

Others factors responsible for the morphological differences in rotifers are food availability and vulnerability to predation (e.g., Stemberger 1988; Garza-Mouriño et al 2005, Gilbert 2009). Gilbert $(1967,1980)$ reported that the formation of defensive lateral spines in B. calyciflorus were an induced response to the chemical presence (i.e., kairomone) of the predator Asplanchna. Similar results were observed in B. quadridentatus Hermann, 1783 (Gilbert 2001), K. tropica (Apstein, 1907) (Gilbert 2009) and P. patulus macracanthus (Daday, 1905) (Sarma et al 2011). In this study, we observed the occurrence of Asplanchna brightwelli Gosse, 1850 in both environments, suggesting that some individuals of Testudinella could develop concavities to avoid predation.

Lastly, concavities may be related to the stage of development. De Smet (2009) suggests that the presence of concavities (called by this author as "flattening") on the lorica of T. elliptica (Ehrenberg, 1834) is related to the development of the vitellarium. It is likely that the same occurrence is applicable to the organisms of both species of Testudinella. We do not discard the possibility that individuals in this study may be newly hatched.

In summary, here we described the presence of concavities in $T$. mucronata and T. patina, suggesting three possible causes for their formation: (i) temperature; (ii) predation; (iii) or recent hatching. However, additional studies are needed to investigate which of these possibilities are responsible for presence of concavities in our exemplars.

\section{Acknowledgments}

We are grateful to Reuben W. Nowell for the English revision. PNC was supported by Conselho Nacional de Desenvolvimento Científico e Tecnológico (CNPq).

\section{Author Contributions}

Paula Nunes Coelho: Collaborated with writing and successive revisions of the manuscript; idealized the study and performed the collections; identified the species.

Louizi Souza Magalhães Braghin: Collaborated with writing and successive revisions of the manuscript; identified the species.

Fabio Amodêo Lansac-Tôha: Collaborated with writing and successive revisions of the manuscript.

Raoul Henry: Idealized the study and performed the collections; collaborated with writing and successive revisions of the manuscript.

\section{Conflicts of interest}

The authors declare that they have no conflict of interest related to the publication of this manuscript.

\section{References}

AHAD, N. \& RAO, R.J. 2017. The nature and causes of cyclomorphosis in some species of Brachionus-Brachionus falcatus and Brachionus forficula. Int. J. Zool. Stud. 2(5): 31-35.

ALVARADO-FLORES, J., RICO-MARTÍNEZ, R., ADABACHE-ORTÍZ, A. \& SILVA-BRIANO, M. 2015. Morphological alterations in the freshwater rotifer Brachionus calyciflorus Pallas 1766 (Rotifera: Monogononta) caused by vinclozolin chronic exposure. Ecotoxicology. 24(4): 915-925.

BIELAÑSKA-GRAJNER, I. 1995. Influence of temperature on morphological variation in populations of Keratella cochlearis (Gosse) in Rybnik Reservoir. Hydrobiologia. 313/314: 139-146.

CASANOVA, SMC, PANARELLI, EA \& HENRY, R. 2009. Rotifer abundance, biomass, and secondary production after the recovery of hydrologic connectivity between a river and two marginal lakes (São Paulo, Brazil). Limnologica. 39(4): 292-301.

CUNHA, D.G.F. \& CALIJURI, M.D.C. 2011. Limiting factors for phytoplankton growth in subtropical reservoirs: the effect of light and nutrient availability in different longitudinal compartments. Lake Reserv. Manag. 27(2):162-172.

CUNHA, D.G.F., CARMO CALIJURI, M. \& LAMPARELLI, M.C. 2013. A trophic state index for tropical/subtropical reservoirs (TSItsr). Ecol. Eng. 60: 126-134.

CUNHA, D.G.F., OGURA, A.P. \& CALIJURI, M.D.C. 2012. Nutrient reference concentrations and trophic state boundaries in subtropical reservoirs. Wat. Sci. Tech. 65(8): 1461-1467.

DE SMET, W.H. 2009. A review of the marine and brackish-water species of Testudinella (Rotifera: Monogononta, Testudinellidae), with the description of two new species. Zootaxa. 2092:1-20.

DIAS, C.D. 1999. Morphological abnormalities on Acartia lilljeborgi (Copepoda, Crustacea) in the Espírito Santo Bay (ES, Brazil). Hydrobiologia. 394: 249-251

ERIKSEN, B.G. 1968. Marine rotifers found in Norway, with descriptions of two new and one little known species. Sarsia. 33(1): 23-34.

FONTANETO, D., SEGERS, H. \& MELONE, G. 2008. Marine rotifers from the Northern Adriatic Sea, with description of Lecane insulaconae sp. nov. (Rotifera: Monogononta: Lecanidae). J. Mar. Bio. Assoc. U. K. 88(2): 253-258.

GARCIA, A.P.P., LANSAC-TÔHA, F.A. \& BONECKER, C.C. 1998. Species composition and abundance of rotifers in different environments of the floodplain of the upper Paraná river, Brazil. Revta Bras. Zool. 15(2): 327-343.

GARRAFFONI, A.R. \& LOURENÇO, A.P. 2012. Synthesis of Brazilian Rotifera: an updated list of species. Check List. 8(3): 375-407. 
GARZA-MOURIÑO, G., SILVA-BRIANO, M., NANDINI, S., SARMA, S. S. S. \& CASTELLANOS-PAEZ, M. E. 2005. Morphological and morphometrical variations of selected rotifer species in response to predation: a seasonal study of selected brachionid species from Lake Xochimilco (Mexico). Hydrobiologia. 546(1): 169-179.

GE, Y., XI, Y., MA, J. \& XU, D. 2018. Factors Influencing Morphological Characteristics of Keratella cochlearis in Lake Tingtang. Proc. Natl. Acad. Sci. India Sect B Biol. Sci. 88(1), 421-428.

GILBERT, J.J. 1967. Asplanchna and postero-lateral spine production in Brachionus calyciflorus. Arch. Hydrobiol. 64: 1-62.

GILBERT, J.J. 1980. Further observations on developmental polymorphism and its evolution in the rotifer Brachionus calyciflorus. Freshwater Biol. 10(3): 281-294.

GILBERT, J.J. 1999. Kairomone-induced morphological defenses in rotifers. In The ecology and evolution of inducible defenses (R. Tollrian \& C.D. Harvell, eds). Princeton University Press, New Jersey, p. 127-141.

GILBERT, J.J. 2001. Spine development in Brachionus quadridentatus from an Australian billabong: genetic variation and induction by Asplanchna Hydrobiologia. 446(1): 19-28.

GILBERT, J. J. 2009. Predator-specific inducible defenses in the rotifer Keratella tropica. Freshwater Biol. 54(9): 1933-1946.

GILBERT, J.J. 2017. Non-genetic polymorphisms in rotifers: environmental and endogenous controls, development, and features for predictable or unpredictable environments. Biol. Rev. Camb. Philos. Soc. 92(2): 964-992.

GILBERT, J.J. 2018. Morphological Variation and Its Significance in a Polymorphic Rotifer: Environmental, Endogenous, and Genetic Controls. BioScience. 68(3): 169-181.

GOLTERMAN, H.L., CLYMO, R.S. \& OHNSTAD, M.A.M. 1978. Methods for physical and chemical analysis of freshwaters. Blackwell Scientific, London (vol 2).

HENRY, R., PANARELLI, E.A., CASANOVA, S.M.C., GRANADO, D.C., MORTARI, R.C. \& ABRA, J. 2011. Plankton richness and abundance in several different hydrological situations in lakes lateral to a river: a case study in the mouth zone of a tributary into a tropical Reservoir. Oecologia Australis. 15(3): 537-558.

LINDSTRÖM, K., \& PEJLER, B. 1975. Experimental studies on the seasonal variation of the rotifer Keratella cochlearis (Gosse). Hydrobiologia. 46(23): 191-197.

MACKERETH, F.J.H., HERON, J. \& TALLING, J.F. 1978. Water analysis: some revised methods for limnologists. Titus Wilson \& Son Ltd, Kendall.

MAIA-BARBOSA, P.M., MENENDEZ, R.M., PUJONI, D.G.F., BRITO, S.L., AOKI, A. \& BARBOSA, F.A.R. 2014. Zooplankton (Copepoda, Rotifera, Cladocera and Protozoa: Amoeba Testacea) from natural lakes of the middle Rio Doce basin, Minas Gerais, Brazil. Biota Neotrop. 14(1): e20134040.

MELO, R.R., COELHO, P.N., SANTOS-WISNIEWSKI, M.J., WISNIEWSKI, C., MAGALHÃES, C.S. 2017. Morphological abnormalities in cladocerans related to eutrophication of a tropical reservoir. J. Limnol. 76: 94-102.

MONTÚ, M. \& GLOEDEN, I. 1982. Morphological alterations in Acartia tonsa (Saco da mangueira, lagoa dos Patos, Brazil). Arq. Biol. Tecnol. 25: 361-369.

KOSTE, W. 1978. Rotatoria. Die Rädertiere Mitteleuropas, begründet von Max Voigt. Überordnung Monogononta. Gebrüder Borntaeger, Berlin, Stuttgart.
R Development Core Team, 2016. A Language and Environment for Statistical Computing. R Foundation for Statistical Computing, Vienna, Austria, ISBN 3-900051-07-0, Available online at: http://www.R-project.org (accessed 26.09.18).

RÍOS-ARANA, J.V., WALSH, E.J. \& ORTIZ, M. 2007. Interaction effects of multi-metal solutions ( $\mathrm{As}, \mathrm{Cr}, \mathrm{Cu}, \mathrm{Ni}, \mathrm{Pb}$ and $\mathrm{Zn}$ ) on life history traits in the rotifer Plationus patulus. J. Environ. Sci. Health A. Tox. Hazard Subst. Environ. Eng. 42(10): 1473-1481.

SARMA, S. S. S. \& ELIAS-GUTIERREZ, M. 1997. Taxonomic studies of freshwater rotifers [Rotifera] from Mexico. Pol. Arch. Hydrobiol. 3(44): 341-357.

SARMA, S.S.S., RESENDIZ, R.A.L. AND NANDINI, S. 2011. Morphometric and demographic responses of brachionid prey (Brachionus calyciflorus Pallas and Plationus macracanthus (Daday)) in the presence of different densities of the predator Asplanchna brightwellii (Rotifera: Asplanchnidae). Hydrobiologia. 662(1): 179-187.

SEGERS, H. 2007. Annotated checklist of the rotifers (Phylum Rotifera), with notes on nomenclature, taxonomy and distribution. Zootaxa. 1564: 1-104.

SEGERS, H. 2008. Global diversity of rotifers (Rotifera) in freshwater. Hydrobiologia. 595: 49-59.

SEGERS, H. \& WALSH, E.J. 2017. The genus Rhinoglena (Rotifera, Monogononta, Ephiphanidae) in North America, with the description of two new species. Zootaxa. 4290(1): 113-122.

SHARMA, B.K. 1990. The genus Testudinella (Eurotatoria: Gnesiotrocha: Testudinellidae) in North-Eastern India. Hydrobiologia. 199: 29-33.

SHARMA, B.K. \& SHARMA, S. 2005. Biodiversity of freshwater rotifers (Rotifera, Eurotatoria) from North-Eastern India. Mitt. Zool. Mus. Berl. 81(1): 81-88.

SHIEL, R.J. 1995. A guide to identification of rotifers, cladocerans and copepods from Australian inland waters. CRCFE Ident. Guide 3: 1-144.

SILVA, C. V. \& HENRY, R. 2013. Aquatic macroinvertebrates associated with Eichhornia azurea (Swartz) Kunth and relationships with abiotic factors in marginal lentic ecosystems (São Paulo, Brazil). Braz. J. Biol. 73(1): 149-162.

SOUSA, F.D.R., ELMOOR-LOUREIRO, L.M.A. \& SOUZA, M.B.G. 2011. Occurrence of abnormalities on labral keel of Coronatella monacantha (Cladocera, Anomopoda, Chydoridae) in a population from Ceará, Brazil. Braz. J. Biol. 71: 797-798.

STEMBERGER, R.S. \& GILBERT, J.J. 1984. Spine development in the rotifer Keratella cochlearis: induction by cyclopoid copepods and Asplanchna. Freshwater Biol. 14(6): 639-647.

STEMBERGER, R.S. 1988. Reproductive costs and hydrodynamic benefits of chemically induced defenses in Keratella testudo. Limnol. Oceanogr. 33(4): 593-606.

STRICKLAND, J.D.H. \& PARSONS, T.R. 1960. A manual of seawater analysis. J. Fish Res. Board Can. 125: 1-18.

WALLACE, R.L., SNELL, T.W., RICCI, C. \& NOGRADY, T. 2006. Rotifera vol. 1: biology, ecology and systematics (2nd edition). In Segers H., \& H. J. Dumont (eds), Guides to the Identification of the Microinvertebrates of the Continental Waters of the World, 23. Kenobi Productions, Gent, Belgium and Backhuys Academic Publishing BV. The Hague, The Netherlands.

XUE, Y.H., YANG, X.X., ZHANG, G. \& XI, Y. L. 2017. Morphological differentiation of Brachionus calyciflorus caused by predation and coal ash pollution. Sci. Rep. 7(1): 15779.

ŻUREK, R. 2006. Response of rotifers to hydrochemical and biotic factors. Oceanol. Hydrobiol. St. 35(2): 121-139. 